\title{
Explaining the low voter turnout in Iceland's 2010 local government elections
}

\author{
Grétar Pór Eypórsson, Marcin Kowalczyk
}

\begin{abstract}
Voter participation in Iceland (measured as voter turnout) was significantly lower in the two most recent local government elections than ever before. In the 2006 local elections, voter turnout in the country dropped below 80 percent for the first time since registration began (to 78.7 percent) and fell even further to 73.4 percent in the 2010 local elections. This article presents data on this drop and seeks potential explanations for it. One hypothesis is that a major factor, especially in the 2010 elections, was disillusionment in the wake of Iceland's economic collapse in 2008 and the subsequent crisis of public confidence in parliament. Another hypothesis is that the size of municipalities has to be taken into account. As elsewhere, political participation in Iceland is stronger in smaller municipalities. It is only in the bigger municipalities in Iceland that nationwide political parties in Iceland are active, and it is also there that voter turnout has dropped the most and voters have given the most support to newly formed political parties.
\end{abstract}

Ágrip: Kosningapátttaka í sveitarstjórnarkosningum á Íslandi hefur verið minni í síðustu tveimur kosningum en nokkru sinni ádur. Í kosningunum 2006 fór pátttaka fyrsta sinni undir 80 prósent síðan skráning hófst, eða i 78,7 prósent. Í sveitarstjórnarkosningunum árið 2010 minnkaði pátttakan enn og varð aðeins 73,4 prósent. Í greininni er petta sýnt með gögnum og leitað að mögulegum skýringum á pessu. Ein tilgáta okkar er að stórminnkuð pátttaka í kosningum 2010 skýrist meðal annars af óánægju kjósenda í kjölfar efnahagshrunsins 2008, sérstaklega eftir að rannsóknarskýrsla Alpingis kom út skömmu fyrir sveitarstjórnarkosningarnar. Önnur tilgáta okkar er að líta verði til stærðar sveitarfélaga í pessu samhengi. Líkt og annars staðar í heiminum er kosningapátttaka á Íslandi meiri í litlum sveitarfélögum en peim stærri. Flokkakerfið á landsvísu er mest til staðar í stærstu sveitarfélögunum. Par hafa kjósendur valið ný stjórnmálaöfl til forystu og kosið í minna mæli en áður.

Citation/Tilvísun: Grétar Pór Eypórsson and Marcin Kowalczyk, "Explaining the low voter turnout in Iceland's 2010 local government elections," Samtíð 1 (2013), 2. http://dx.doi.org/10.12742/samtid.2013.2

Received/Móttekið: 2011-02-28. Accepted/Sambykkt: 2012-10-09. Published/Birt: 2013-03-26.

(c) 2013 Authors/Höfundar. This open-access article is published under the terms of the Creative Commons Attribution License, version 3.0 / Greinin er birt i opnum

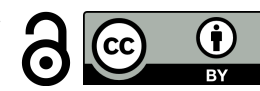
aðgangi undir CC-BY 3.0 leyfi (http://creativecommons.org/licenses/by/3.0) 


\section{Introduction}

Voter participation (measured as voter turnout) in Iceland was significantly lower in the two most recent local government elections than ever before. In the 2006 local elections, the average turnout in the country dropped below 80 percent for the first time since registration began (to 78.7 percent) and fell even further to 73.4 percent in the 2010 local elections. This article presents data on this drop and seeks potential explanations for it.

Party representation at the local level in Iceland has always been weak. In the 1990 local elections, the four parties represented in the parliament (the Alpingi) only won 26 percent of the seats in local councils (Eythórsson, 1999). This rate has increased over time; in the 2006 elections 54 percent of local council seats were held by the parties in parliament and in 2010 the rate was also 54 percent. ${ }^{1}$ Still, close to half of the seats are held by locally organized lists that do not play a role in the national political arena. ${ }^{2}$ However, in the four municipalities that are the largest by far - Reykjavík, Kópavogur, Hafnarfjörður and Akureyri - the national parties have held almost all of the seats for decades. National politics seem to have been well represented in Iceland's largest municipalities, but to a much lesser extent in the smaller ones. Icelandic political scientist Gunnar Helgi Kristinsson has shown that partisan politics are significantly more evident in municipalities with more than 1000 inhabitants, and especially so when the population exceeds 2000 (Kristinsson, 2001, pp. 106-108).

We lack a complete account and analysis of national party presence in local elections in Iceland. But we can put the issue in a comparative perspective: research on Norwegian municipalities has shown that the rate of "non-partisan" representation is much lower, with non-partisan lists holding between 11 and 21 percent of the total local council seats between 1983 and 2003 (Aars and Ringkjøb, 2005). According to Aars and Ringkjøb, the rate in Norway falls as municipal size increases, just as it appears to do in Iceland. The rate for Norwegian municipalities with 20,000 inhabitants or more was below 10 percent (with one exception), while in the smallest municipalities (with less than 2,500 inhabitants) it was considerably higher: 18-32 percent. The main trend in Norway in the post-war period is that non-partisan lists have, over time, won a smaller and smaller share of council seats. Despite limited and fragmented data

1 These figures were calculated from the local election database on the Statistics Iceland website (www.statice.is).

2 These figures do not distinguish between the various types of locally organized lists. A considerable proportion of them have, through the years, been alliances between parties which are distinct at the national level, mostly joint left-wing lists or lists formed jointly by left-wing and centrist parties. 
and research on this subject in Iceland, the trend seems to be in the same direction as in Norway, even though locally organized lists have considerably higher representation.

The Icelandic local government elections on 29 May 2010 were in many ways of historical significance, with striking results in some municipalities. As pointed out earlier, in small and medium-sized municipalities non-partisan lists have been common for decades. But in the 2010 elections, completely new parties and lists put forth candidates in some of the biggest municipalities - and won. In Reykjavík, the capital, a new protest party called "Besti Flokkurinn" (the Best Party), led by the well-known comic actor Jón Gnarr, won 35 percent of the vote and six out of 15 seats on the city council. In Akureyri, the fourth biggest municipality and largest city in north Iceland, a party outside the traditional system called "Listi fólksins" (the People's List) won 45 percent of the vote and six out of 11 seats on the city council, an absolute majority. ${ }^{3}$ In Kópavogur, a suburb of Reykjavík and Iceland's second-biggest municipality, two completely new, outsider parties competed. "Næstbesti flokkurinn" (the Second-Best Party) won approximately 14 percent of the vote (and one council seat) while "Listi Kópavogsbúa" (the List of the People of Kópavogur) received 11 percent and one seat. Both these new parties became part of the majority coalition for the 2010-2014 term. ${ }^{4}$ This new trend in party representation in the big municipalities is something worth looking at and is evidence of certain challenges to Iceland's traditional party system, at least at the local level.

\section{Icelandic voter turnout in historical perspective}

Looking as far back as data has been collected, voter participation in Icelandic local government elections always fluctuated between a maximum of 87.8 percent and a minimum of 81.9 percent - until the 2006 elections, when it dropped below 80 percent for the very first time, to 78.7 percent. In the 2010 local elections voter turnout reached a new record low of 73.4 percent. In parliamentary elections, the long-term trend in participation in Iceland is also clearly downward. Parliamentary election turnout is, however, historically high compared to other Western European countries. Over the period from 1950 to 2005, the average rate was 87.7 percent. Only Malta, Luxembourg

3 Listi Fólksins was not a completely new phenomenon in Akureyri local politics. It had won seats in the election of 1998 ( 1 seat), 2002 ( 2 seats), and 2006 (1 seat). With six seats, the 2010 results represented a significant breakthrough.

4 In both Akureyri and Reykjavík, "merged lists" consisting of alliances of the traditional parties had held power during parts of the previous two decades. In Reykjavík, "R-listinn" was an alliance of traditional left-wing and moderate parties. It won a majority in 1994 and survived until the 2006 elections, when the parties involved decided to end their cooperation. In Akureyri, a left-wing merged list, "Akureyrarlistinn," held the majority between 1998 and 2002. 
and Belgium have higher average rates during that period (Bengtsson, 2008, p. 89; see also Kristinsson, 2007, p. 51).

Figure 1 shows voter participation in local government elections (the lower line) and parliamentary elections (the upper line) since $1962 .{ }^{5}$

Figure 1. Participation in parliamentary and municipal elections in Iceland, 1962-2010. Source: data from Statistics Iceland (www.statice.is).

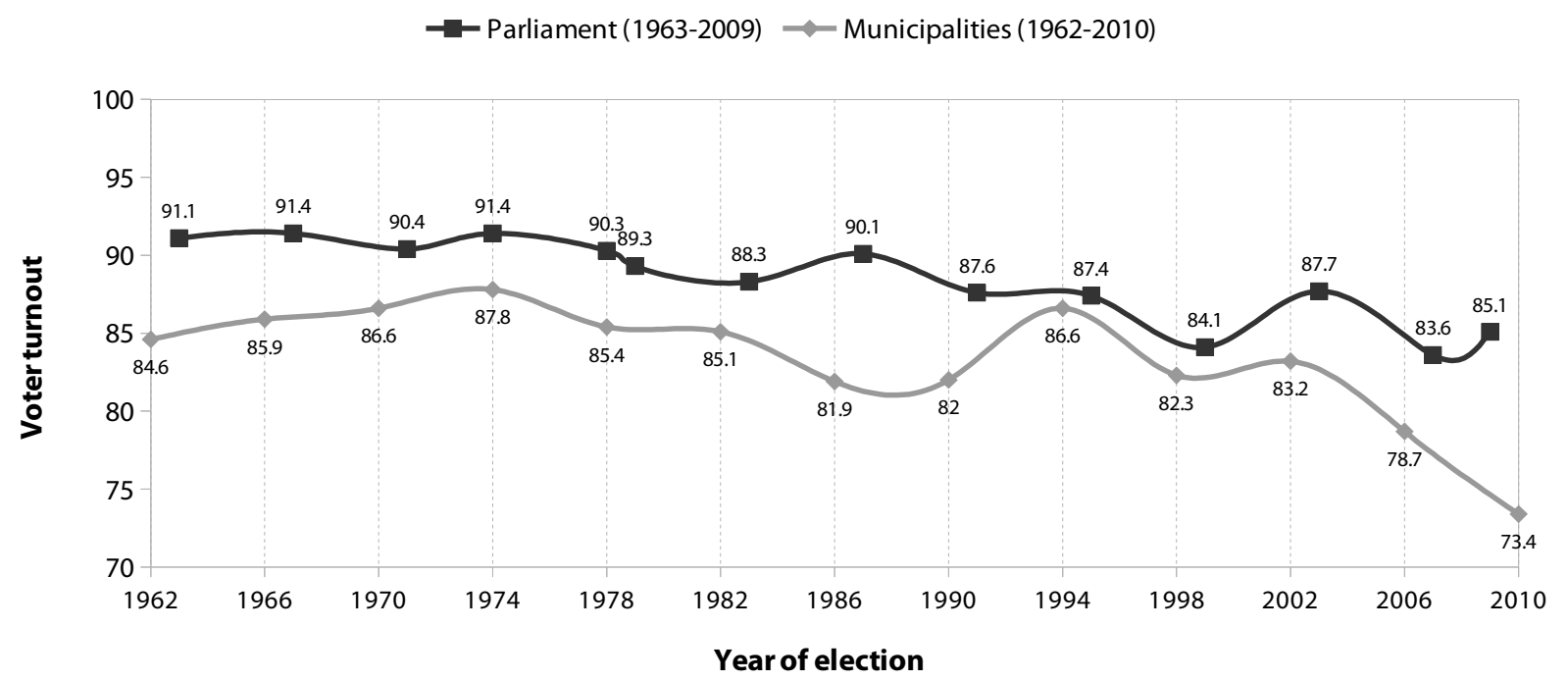

Participation in parliamentary elections was higher than in local government elections throughout the period shown in Figure 1. The average turnout rates for the entire period differ clearly: 83.3 percent for local elections and 88.4 percent for parliamentary elections. Since 2006, and especially in the most recent elections, the difference has widened. Participation in local elections has dramatically decreased, but that has not been the case with parliamentary elections. When the 2009 parliamentary elections and the 2010 local elections are compared the difference in turnout is 11.7 percentage points, much greater than the average of just over 5 percent for the whole period.

Overall, turnout in local elections has been sharply decreasing in Iceland. Participation in parliamentary elections has been somewhat more stable - but has also been falling.

5 Local and parliamentary elections in Iceland are not usually held at the same time. During the period shown in the chart they have, however, twice been held in the same year (in 1974 and in 1978). Local elections have been held regularly every four years. Instability in national government coalitions, especially in the 1970s, led to coalition breakups in 1974, 1979, and 2009 and ultimately to new parliamentary elections before the mandate period was over. 


\section{Promising hypotheses}

Looking at these facts led us to try to find possible reasons for the developments we observed: the decreasing turnout in local government elections in 2006-2010, and especially in 2010. We will focus on two main possible explanations.

The first is Iceland's economic collapse in 2008. This caused dramatic changes in Icelanders' economic situation, leading to an equally dramatic collapse in people's trust in government, politics, and politicians. One hypothesis is that dwindling trust in politicians resulted in declining interest in voting - particularly in the 2010 local elections. A second hypothesis is based on the idea that there is a relationship between the number of inhabitants in a municipality and their interest in politics. This relationship is reflected in voter participation, which in Iceland is higher in smaller municipalities, and specific events (municipal amalgamations and disaffection with national political parties) may have intensified this relationship around the 2006 and 2010 elections.

Here it is important to mention that, since 1993, many municipalities in Iceland have amalgamated. Two general local referenda on amalgamations were held in 1993 and 2005, and other amalgamations have taken place separately. The number of municipalities has fallen from 196 (in 1993) to 105 (in 2002) to 76 (in 2010). This has led to a rise in the average population of Icelandic municipalities, from 1339 inhabitants in 1993 to 4179 inhabitants in 2010. If there is a relationship between municipal population size and voter participation, an increasing average municipal population size in Iceland could possibly lead to less political interest and activity. In other words, the trend towards larger municipalities in Iceland could partially explain decreasing participation in local government elections. However, this might not hold true if, in this relationship, municipal population size is a proxy for other factors which do not necessarily change when two municipalities amalgamate and the population (technically speaking) rises.

\section{Theories about declining voter participation}

A number of other theorists have put forth ideas and hypotheses to explain decreasing election participation in western democracies. Most have, on the whole, focused on more general explanations than we intend to do here. The ideas with the most relevance to the Iceland case are those of Dahl and Tufte (and their followers) on unit size and democracy; these are discussed below.

The other main attempts at explaining decreasing voter participation fall into two kinds (for an overview, see Bengtsson 2008). The first kind of hypothesis points up the loosening linkages between political parties and special interests and interest organizations in society. Without these linkages it is increasingly difficult for the parties to 
mobilize voters to participate. This leads to decreasing election participation (Powell, 1982; Wattenberg, 2000). The second approach originates with Mark Franklin, and bases its argument on the idea of generational changes among voters. According to Franklin, decreasing participation is a long-term effect of reducing the voting age to 18 years during the 1970s and 1980s. Franklin claims that people aged between 18 and 20 are in a period of life where they are less likely to participate in elections (Franklin, 2004).

We believe that neither of these two hypotheses about the reasons for shrinking voting participation is particularly useful in explaining the rapid decrease in participation in local government elections in Iceland in 2006 and 2010.

\section{The 2008 economic collapse in Iceland}

Within a week in October 2008 the three main banks in Iceland collapsed. These banks made up 85 percent of the Icelandic banking system. The people of Iceland experienced a very deep and rapid financial crisis. This led to a dramatic increase in Icelandic state debt, a sharp devaluation of the Icelandic króna, rapidly increasing unemployment, and, in turn, a turbulent situation in Icelandic society. After repeated protests and a near-riot outside the parliament building in Reykjavík, the governing coalition (formed by the Social Democrats and the right-wing Independence Party) broke up. After three months of a minority government by the Social Democrats and the Left-Green Party, new elections were held on 25 April 2009. The two minority government parties gained a majority, obtaining 34 out of 63 seats in Parliament.

In retrospect, the causes of the crash were easy to see. In the late 1990s and the years following the turn of the millennium, previous governments (coalitions between the Independence Party and the Progressive Party) had deregulated and privatized the Icelandic banking system. The banks proceeded to take advantage of ample low-cost capital in international markets to fuel a high degree of leverage and to grow their balance sheets rapidly. The banks quickly outgrew - by far - the ability of the Central Bank (Seðlabankinn) and other fiscal authorities to stand behind them. The banks' institutional structures also lagged behind those in the banking sector elsewhere. Neither the Central Bank nor Iceland's Financial Supervisory Authority (Fjármálaeftirlitið) received support to create the infrastructure necessary to regulate the banking sector productively (Daníelsson and Zoega, 2009). After the crash, considerable criticism and anger was directed against the pre-collapse governments seen as responsible for Iceland's troubles. Much has now been written about the Icelandic financial collapse. For a brief, easily accessible overview, see Eythórsson, Gylfason, and Jahn (2011). 
In 2009, the Icelandic parliament established an independent Special Investigation Commission (Rannsóknarnefnd Alpingis; here called the SIC) which was given the task of investigating the causes of the economic collapse. On 12 April 2010 the commission presented its report, which blamed the government, the Central Bank, and the Financial Supervisory Authority for negligence in the exercise of their duties before the crash, and even suggested that some of the politicians and public officials named in the report could be held legally responsible (Hreinsson et al., 2010). The report exposed deep flaws in Iceland's public administration, which had weakened the country's infrastructure and contributed to the disastrous economic collapse. The parliamentary elections in April 2009 were very close in time to the collapse and the dramatic incidents that followed. The SIC report, with its shocking conclusions and accusations, was released to the public not quite seven weeks before the local government elections in 2010. Our question is whether these events affected voter participation in these elections.

\section{Increasing discontent in Icelandic society}

In the autumn of 2009, Icelandic political scientists Eva Heiða Önnudóttir and Ólafur Harðarson published an article whose title translates as "Discontented democrats" (Önnudóttir and Harðarson, 2009; see also Önnudóttir and Harðarson, 2011). In it they present results from electoral surveys in connection with the parliamentary elections of 1999, 2003, 2007 and 2009. These surveys asked questions about democracy both as an idea and as a practice, and the authors' work focused on whether these data showed any signs of decreasing trust in democracy among the Icelandic people. An underlying question was whether the economic collapse had precipitated a legitimacy crisis for the entire Icelandic state. Önnudóttir and Harðarson base their theoretical framework on, for example, Russell J. Dalton, who concluded that trust in politicians and political institutions has been decreasing since the mid-20th century in Great Britain, the USA, Germany, and France, but that the people in these countries still believe strongly in democracy as an idea.

In their article Önnudóttir and Harðarson present striking data on the differences in Icelanders' perceptions before and after the 2008 collapse. For example, the proportion of those surveyed who were satisfied with how democracy works in Iceland declined from 79 percent in 1999 to 42 percent in 2009. The proportion who believed that Iceland is governed according to the people's will fell from 64 percent in 2007 to 31 percent in 2009. The proportion who believed that corruption is rather common or very common among politicians increased from 30 percent in 2003 up to a noteworthy 77 percent in 2009 (Önnudóttir and Harðarson, 2009). 
These results show us that the events of autumn 2008 and their aftermath had not only a strong economic impact on the people of Iceland, but also an effect on the way they think about politics, which has manifested itself in sharply declining trust in politicians and political institutions.

Önnudóttir and Harðarson's data predates the report from the SIC in April 2010 and its powerful impact, which further undermined the legitimacy of politicians and political institutions. However, regular surveys carried out by Capacent in Iceland (bjóðarpúls) contain questions on trust in various institutions in society. The proportion of those surveyed who professed trust in the Icelandic parliament (Alpingi) was 42 percent in February 2008. One year later, in the wake of the collapse, this was down to 13 percent; in September/October 2010 the level of confidence had shrunk to 9 percent. In February 2012 it was at 10 percent (Capacent, 2010, 2012). This shows that trust in politicians and political institutions not only decreased dramatically after the collapse of 2008, but stayed low after the SIC report was published (even if it does not specifically show that the report was a factor).

It is reasonable to hypothesize that this post-collapse dissatisfaction may have surfaced in lower voter turnout for the 2010 municipal elections. This does, however, raise the question of why there was no drop in participation in the parliamentary elections of 2009. One could hypothesize that the 2009 elections followed the collapse too closely (by a little more than half a year) and that one year further on, and after the publication of the SIC report, people had had time to sort things out.

\section{The role of population size in voter turnout}

In their classic 1974 study on the relationship between size and democracy, Dahl and Tufte found evidence that unit size has a clear impact on both voter participation and democratic effectiveness (when looking at units within countries). They referred to results from a Swedish study which showed that participation and effectiveness were significantly higher in municipalities with less than 10,000 inhabitants (Dahl and Tufte, 1974).

More recent findings also support the hypothesis that democracy weakens with increasing population size. Surveys conducted in Switzerland, Norway, Denmark and the Netherlands suggest that "population size has a more or less consistent effect on two of the four forms of local political participation - party activity and contacting across the four countries considered" (Denters and Rose, 2008). The same authors also presented evidence suggesting a size effect on the likelihood of voting in the Netherlands and Norway, and conclude: "To the extent evidence of a size effect was found, it was in all instances negative: people's participation shows propensity to decline with 
increasing municipal population size" (Denters and Rose, 2008). Furthermore, a number of other studies have concluded that there is a clear correlation between municipal population size and voter participation - the bigger the municipality, the lower the rate of participation (Morlan, 1984; Goldsmith and Rose, 2000; Sundberg, 2000; Frandsen, 2002; Frandsen, 2003).

These studies lend plausibility to our second hypothesis, that increasing municipal population size can to some degree account for declining voter participation in Iceland. This could be true even though the average size of municipalities is much lower in Iceland than in the other countries that have been studied. Today, for example, only 6 out of 75 municipalities in Iceland have more than 10,000 people.

\section{Voter turnout in Icelandic local government elections by municipal population size}

Table 1 presents data on the turnout in the last six local government elections (19902010) for Icelandic municipalities sorted into five groups according to their population size. We see that even though turnout has been decreasing overall, the degree of decrease has not been the same in all groups.

Table 1. Average voter turnout in local government elections in Iceland for municipalities of different population sizes, 1990-2010 (\%). The data shown are the mean values of the turnout figures for all the municipalities in a given population category. Source: data from Statistics Iceland (www.statice.is).

\begin{tabular}{llllllll}
\hline Municipal population & 1990 & 1994 & 1998 & 2002 & 2006 & 2010 & Mean standard deviation \\
\hline Less than 500 & 75.6 & 80.1 & 78.9 & 80.0 & 76.5 & 79.1 & 10.4 \\
$500-999$ & 89.7 & 87.8 & 87.3 & 86.9 & 87.6 & 81.9 & 5.3 \\
$1000-2499$ & 87.9 & 88.7 & 87.6 & 87.5 & 86.1 & 82.1 & 4.0 \\
2500-10,000 & 84.6 & 85.7 & 82.9 & 83.8 & 82.3 & 75.7 & 3.8 \\
More than 10,000 & 79.7 & 85.1 & 79.7 & 82.4 & 77.1 & 70.7 & 3.3 \\
\hline Pearson’s r & .056 & .082 & .017 & .025 & .092 &.-197 & \\
ETA (grouped) & $.455^{\star *}$ & $.363^{\star *}$ & $.435^{\star *}$ & $.415^{\star *}$ & $.545^{* *}$ & $.409^{*}$ & \\
\hline
\end{tabular}

It is clear from Table 1 that the most significant drop in turnout in 2006 and 2010 was in municipalities with a population of more than 10,000. Municipalities with 100010,000 inhabitants show a slight drop in 2006 followed by a much larger drop in 2010. In municipalities with 500-999 inhabitants the turnout drop did not really take place until 2010, and in the smallest municipalities (with less than 500 inhabitants) there has been no drop (on average). While the overall trend from 1990-2010 is one of reduced 
turnout, in the smallest municipalities turnout has been more or less stable. Figure 2 illustrates these trends graphically.

Figure 2. Average voter turnout for municipalities of different population sizes in local government elections in Iceland, 1990-2010 (\%).

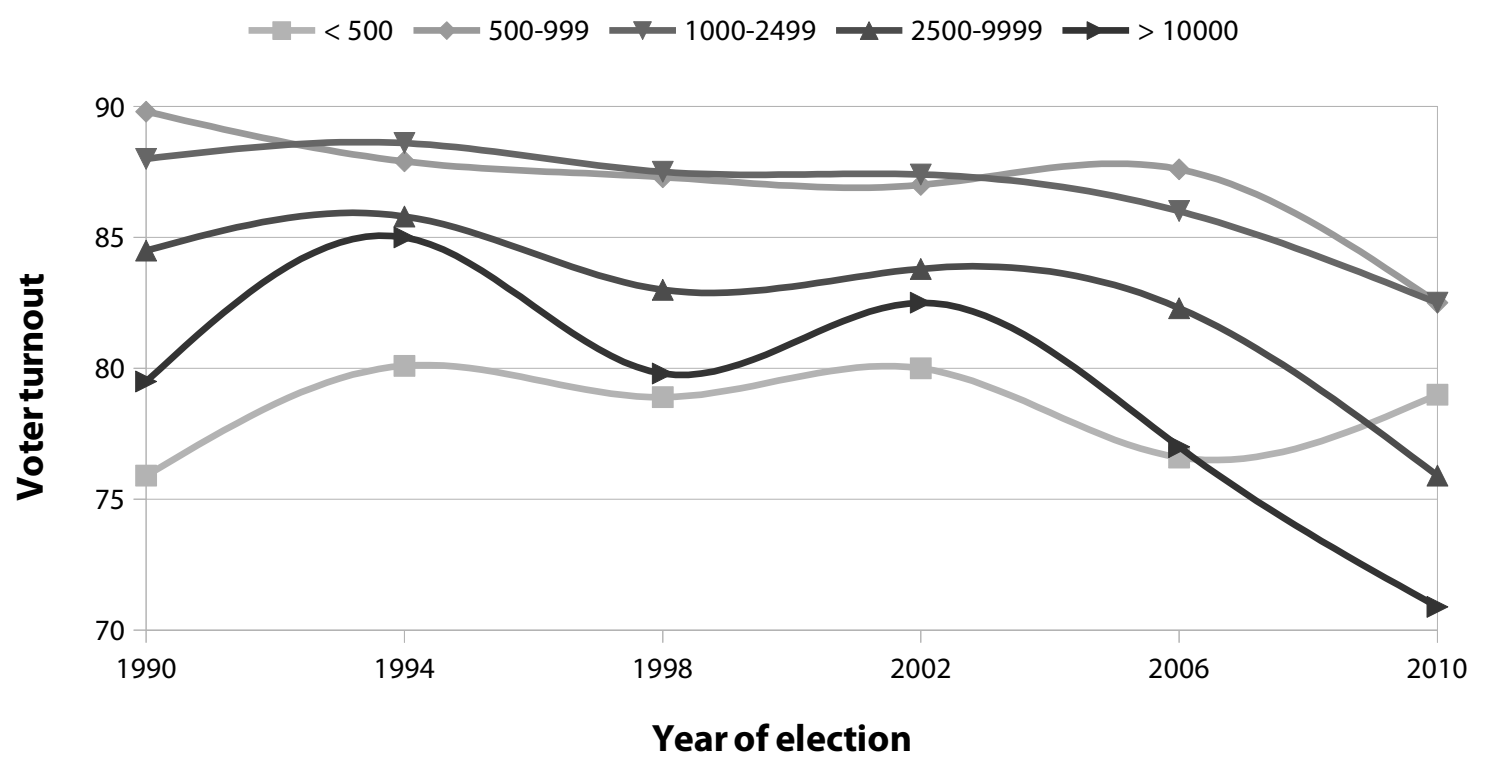

This data tells us that even though the general trend in Iceland is towards decreasing voter turnout, the rate of decrease is size-dependent. The rapid decrease that one sees in overall statistics for the 2006 and 2010 elections did not take place in the smaller municipalities. The correlation coefficients in Table 1 above show the development of a negative relationship between population size and turnout in the 2010 elections.

\section{Turnout in Iceland's five largest municipalities}

Another way to understand recent developments in voter turnout in Iceland is to look at statistics for Iceland's five most populous municipalities, those with over 10,000 inhabitants during the period studied. (Garðabær, a suburb of Reykjavík which reached the 10,000 mark in 2009, is excluded here.) Figure 3 illustrates this development. Hafnarfjörður and Kópavogur are suburban towns in the greater Reykjavík area, Reykjanesbær is made up of the towns near Iceland's international airport, and Akureyri is the largest town in northern Iceland. What is interesting here is that the turnout in all five municipalities dropped to 65-75 percent in 2010 after having mostly ranged between 75 and 90 percent in previous years. In all cases we see a clear negative trend for the period - with the exception of the 1990 elections in Akureyri. In all municipalities there was a significant drop between 2006 and 2010. 
Figure 3. Voter turnout in local government elections in the five largest municipalities in Iceland, 1990-2010 (\%).

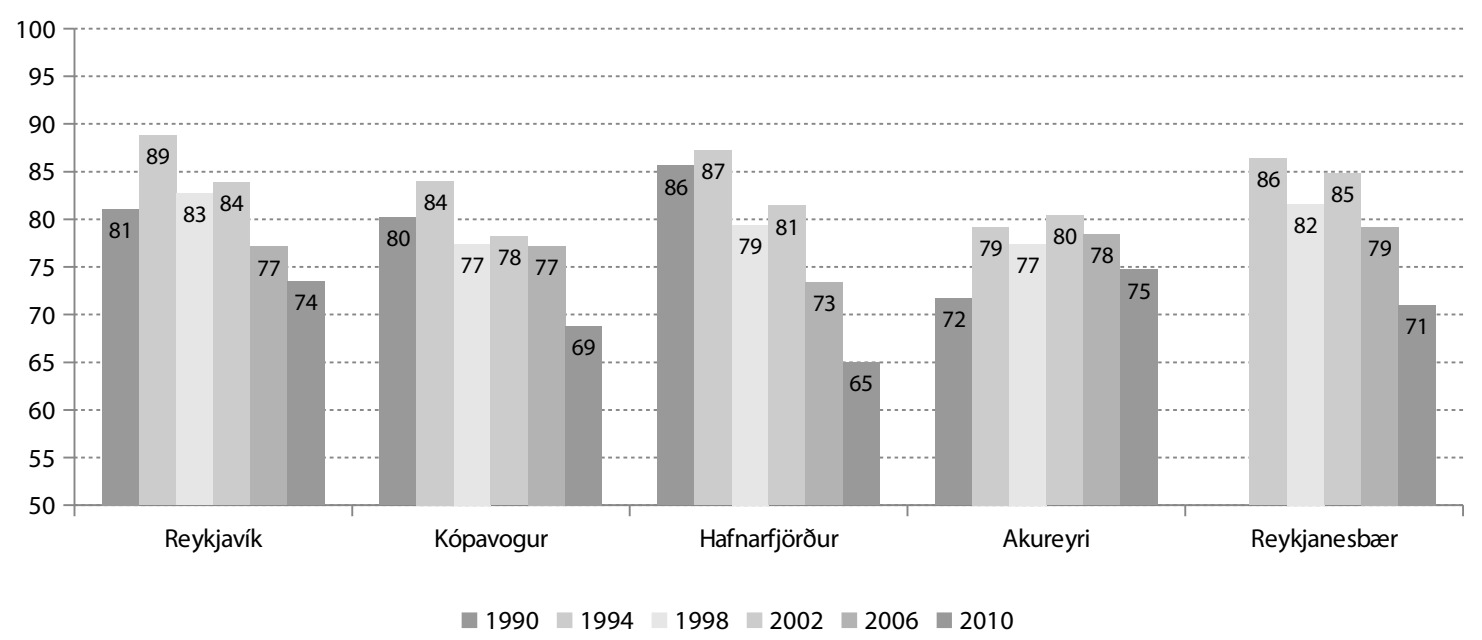

Table 2, below, highlights the drop in turnout in these five municipalities in 2010 by comparing 2010 turnout with the average turnout from the period 1990-2006:

Table 2. Voter turnout in the five largest Icelandic municipalities in 2010, compared with the average turnout between 1990 and 2006 (\%).

\begin{tabular}{llll}
\hline Municipality & $\begin{array}{l}\text { 1990-2006 } \\
\text { (average) }\end{array}$ & 2010 & $\begin{array}{l}\text { Change between the 1990- } \\
\text { 2006 average and 2010 }\end{array}$ \\
\hline Reykjavík & 82.7 & 73.5 & -9.2 \\
Kópavogur & 79.4 & 68.8 & -10.6 \\
Hafnarfjörður & 81.4 & 65.0 & -16.4 \\
Akureyri & 77.4 & 74.7 & -2.7 \\
Reykjanesbær & 83.0 & 71.0 & -12.0 \\
\hline
\end{tabular}

Compared with the average turnout from 1990-2006, the drop in 2010 is between 9.2 and 16.4 percentage points, with the exception of Akureyri where it is only 2.7 points.

The question is, then, what factors might explain why there was a big drop in participation in Iceland's larger municipalities but a smaller drop, or none at all, in the smaller ones?

One hypothesis is that the stronger role of Iceland's national parties in the larger municipalities contributed to a drop in voter participation there. Recall that national parties are represented in local elections mostly just in Iceland's larger municipalities. Voter turnout in the local government elections falls most dramatically in the larger municipalities, where the nationwide parties are more frequently represented, and 
much less in the smaller municipalities, where they are hardly represented at all. The four main national parties (or even just some of them) may have been seen as bearing responsibility for Iceland's economic difficulties, and voters who might otherwise have supported those parties in local elections may have stayed home as a result. In smaller municipalities, where the lists and parties on offer were more home-grown and had fewer links to the national parties towards which voters might have felt animosity, there may have been more of an incentive to participate.

A specific finding that lends plausibility to this hypothesis comes from a 2000 survey in which the Icelandic political scientist Gunnar Helgi Kristinsson found evidence of a relationship between municipal size and inhabitants' perception of being able to influence politics on the local level. In municipalities with more than 10,000 people, the perception of influence was significantly lower than in smaller municipalities, especially those with fewer than 500 inhabitants (Kristinsson, 2001).

\section{Conclusion}

The data presented here shows clear trends that are in need of explanation. A longstanding but only slight downward trend in voter turnout in Iceland, in both parliamentary and local elections, intensified at the local level in 2006 and 2010. Looking more carefully at the available data shows that this drop affected the largest municipalities sooner and to a greater degree than the smaller ones, and that the smallest municipalities were basically unaffected.

The variation by size in this drop is consistent with observations from previous international research on the relationship between municipal size and political participation. Beyond this, we have only been able to hypothesize about the exact mechanisms by which this took place. But we have called attention to some important facts that might contribute to an explanation of declining voter turnout in recent local elections in Iceland.

First, trust in government in Iceland decreased sharply in the wake of the 2008 economic crash and even more so after the release of the SIC report in early 2010, and this could have contributed to a lack of interest in local elections. The established political parties in Iceland are more active in the larger municipalities; if voters felt particular resentment towards them, it would be mostly likely to be visible there. In general, Icelandic voters who live in smaller municipalities report feeling that they have more of an influence on politics than those who live in larger municipalities. We lack a clear explanation for why there was a lower turnout for the 2010 local elections but a fairly good turnout in the 2009 parliamentary elections; however, the strong presence of completely new political parties at the local level (but not at the national level) may 
have been a factor. Another unanswered question is why the drop in local election turnout in larger municipalities started in 2006, two years before the economic crash. Although our conclusions in this article are by necessity only very tentative, the data that we have presented is interesting and it raises compelling questions. We hope that further analysis and, perhaps, more data from elections over the coming years will deepen our understanding of voter turnout trends in Iceland.

\section{About the authors}

Grétar Pór Eypórsson is a professor at the University of Akureyri, Iceland. E-mail: gretar@unak.is. Marcin Kowalczyk is a scientist at the University of Warmia and Mazury, Olsztyn, Poland. E-mail: marcin.kowalczyk@uwm.edu.pl. The authors wish to thank Eva Heiða Önnudóttir and the anonymous reviewers for their helpful comments.

\section{References}

Aars, J., and Ringkjøb, H. (2005). "Party politicisation reversed? Non-partisan alternatives in

Norwegian local politics." Scandinavian Political Studies 28, 2: 161-181.

http://dx.doi.org/10.1111/j.0080-6757.2005.00126.x

Bengtsson, Å. (2008). Politiskt deltagande. Lund: Studentlitteratur.

Capacent (2010). “Traust til Alpingis.” pjóðarpúlsinn, 20 October 2010. Available at http://capacent.is/frettir-og-frodleikur/thjodarpulsinn/thjodarpulsinn/2010/10/20/Traust-tilAlthingis

Capacent (2012). “Traust til stofnana." Pjóðarpúlsinn, 6 March 2012. Available at http://www.capacent.is/frettir-og-frodleikur/thjodarpulsinn/thjodarpulsinn/? NewsID=1624adf0-c5ec-499f-bedf-c1b40a122274

Dahl, R. A. and Tufte, E. R. (1974). Size and democracy. London: Oxford University Press.

Dalton, R. J. (2008). Citizen politics: public opinion and political parties in advanced industrial democracies. 5th edition. Washington: CQ Press.

Danielsson, J. and Zoega, G. (2009). “The collapse of a country: second edition.” Unpublished paper, 12 March 2009. Available at http://www.riskresearch.org/files/e.pdf

Denters, B. and Rose, L. E. (2008). "Municipal size and local political participation: findings from Switzerland, Norway, Denmark and the Netherlands." Paper prepared for the 2008 Annual Meeting of the American Political Science Association, 28-31 August 2008.

Eythórsson, G. Th. (1999). “The Iceland national report.” Pages 62-88 in Jacob, B., Linder, W., Nabholz, R. and Heierli, C. (eds.), Democracy and local governance: nine empirical studies. Institute of Political Science, University of Bern.

Eythórsson, G. Th., Gylfason, T., and Jahn, D. (2011). "Iceland report." Part of Sustainable Governance Indicators 2011. Gütersloh: Bertelsmann Stiftung. Available at http://www.sginetwork.org/pdf/SGI11_Iceland.pdf

Frandsen, A. G. (2002). "Size and electoral participation in local elections." Environment and Planning C: Government and Policy 20, 6: 853-869. http://dx.doi.org/10.1068/c0228 
Frandsen, A. G. (2003). "Deltagelse ved kommunalvalg." Pages 109-126 in Kjær, U. and Mouritzen, P. E. (eds.), Kommunestørrelse og lokalt demokrati. Odense: Syddansk Universitetsforlag.

Franklin, M. N. (2004). Voter turnout and the dynamics of electoral competition in established democracies since 1945. Cambridge: Cambridge University Press.

Goldsmith, M. and Rose, L. E. (2000). "Constituency size and electoral politics: a comparison of patterns at local elections in Norway and the UK." Paper presented at the IPSA XVIII World Congress, Quebec, 1-5 August 2000.

Hreinsson, P., Benediktsdóttir, S., and Gunnarsson, T. (eds). (2010). Aðdragandi og orsakir falls íslensku bankanna 2008 og tengdir atburðir. 9 vols. Reykjavík: Rannsóknarnefnd Alpingis.

Kristinsson, G. H. (2001). Staðbundin stjórnmál: markmið og árangur sveitarfélaga. Reykjavík: Háskólaútgáfan.

Kristinsson, G. H. (2007). Íslenska stjórnkerfið. Reykjavík: Háskólaútgáfan.

Morlan, R. L. (1984). "Municipal vs. national election voter turnout: Europe and the United States." Political Science Quarterly 99, 3: 457-470.

Önnudóttir, E. H. and Harðarson, Ó. Th. (2009). “Óánægðir lýðræðissinnar: afstaða Íslendinga til lýðræðis.” Pages 223-232 in Guðmundsson, H. S. and Ómarsdóttir, S. B. (eds.), Rannsóknir í félagsvisindum X: félagsráðgjafardeild og stjórnmálafroeðideild. Reykjavík: Félagsvísindastofnun Háskóla Íslands.

Önnudóttir, E. H. and Harðarson, Ó. Th. (2011). "Policy performance and satisfaction with democracy." Stjórnmál og Stjórnsýsla 7, 2: 417-436. http://hdl.handle.net/1946/10401

Powell, G. B. (1982). Contemporary democracies: participation, stability, and violence. Cambridge: Harvard University Press.

Wattenberg, M. P. (2000). “The decline of party mobilization.” Pages 64-78 in R. J. Dalton and M. P. Wattenberg (eds.), Parties without partisans: political change in advanced industrial democracies. Oxford: Oxford University Press. 